\title{
Corporate Wellness Programmes, Employee Efficiency and Job Performance among the Middle Level Executives of Standard Group Limited, Nairobi Kenya
}

\author{
Stephen Musau Mulwa, Prof. Michael M. Ndurumo \\ University of Nairobi, Kenya
}

\begin{abstract}
The study seeks to establish the relationship between corporate wellness programmes, employee efficiency and job performance. Maslow's hierarchy of needs and Herzberg's dual factor theories form the theoretical framework of the study. Eleven (11) departments were sampled for the study using Stratified sampling technique. The sample of the study consists of all the middle level executives working with Standard Group Ltd. Quantitative research design was used in the study by conducting a survey. Data collection was done using questionnaires. Data analysis was carried out using the Statistical Package for Social Sciences (SPSS). Correlation between the variables of the study was calculated using the Pearson ProductMoment Correlation Coefficient. The study found out that the Company offers corporate wellness programmes. A strong correlation exists between corporate wellness programmes and employee efficiency. However, there is no significant correlation between corporate wellness programmes and Job performance. The study concludes that corporate wellness programmes increase employees' efficiency.
\end{abstract}

\section{INTRODUCTION}

G lobally, non-communicable diseases are on the rise due To poor lifestyles (Matunda, 2014). Medical practitioners unanimously agree that unhealthy foods, drinks and lack of physical exercise lead to increased cases of noncommunicable diseases (Makumi, 2015). Lifestyle diseases lead to increased rate of disability and death among the general population (Ligami, 2012). In organizations, noncommunicable diseases result in adverse effects such as high medical costs, absenteeism, presenteeism, low job satisfaction, high employee turnover, low efficiency, reduced return on investment, decreased job performance, increased work-related accidents, reduction of employee morale, decreased employee engagement and proneness to illnesses (Mattke, Liu, Caloyeras, Huang, van Busum, Khodyakov, \&Shier, 2013; Mattke, Schnyer \& Busum, 2012). Consequently, lifestyle diseases inhibit the competitive ability of organizations due to the high costs incurred while addressing the negative effects of employee poor health (MetLife, 2013; Mattke et al., 2013).

Concerns about employee' health and wellbeing pose a great challenge to employers and governments alike. According to
Independence Blue Cross (2013), the US health care sector is in crisis because $75 \%$ of healthcare budget is spent on the treatment of chronic and lifestyle diseases despite that the conditions are preventable. Several studies have cited fatigue, stress and depression as the main causes of low job performance in organizations (Atkinson, 2004). Other studies state that chronic and lifestyle diseases such as depression, overweight, diabetes, cardiovascular diseases and obesity are a major threat to the health and wellbeing of employees.

The Commonwealth Fund survey data provides us with an economic estimate in order to contextualize the effects of health problems on employee performance. "In 2003, an estimated that 18 million adults ages 19 to 64 were not working and had a disability or chronic disease, or were not working because of health reasons. Sixty-nine million workers reported missing days due to illness, for a total of 407 million days of lost time at work. Fifty-five million workers reported a time when they were unable to concentrate at work because of their own illness or that of a family member, accounting for another 478 million days. Together, labor time lost due to health reasons represents lost economic output totaling \$260 billion per year. Workers without paid time off to see a physician are more likely to report missing work or being unable to concentrate at their job." (Davis, Collins, Doty, Ho, \& Holmgren, 2005, pg 1.).

According to Ligami (2012), 10\% of the world's population has raised glucose levels, leading to the development of diabetes. If the diabetes is left untreated, it often leads to cardiovascular diseases, blindness and kidney failure. In Africa, most cases of lifestyle diseases remain undiagnosed, leading to death and disability. Non-communicable diseases such as cardiovascular diseases, diabetes, chronic respiratory diseases and cancer are the leading causes of death among men aged 60 years and below in East Africa. In Kenya, 57\% of men and $47 \%$ women die annually from noncommunicable diseases, with Kenya being ranked number one in East Africa in behavioural risk factors that lead to life-style diseases. For instance, women in Kenya are reported to be more physically inactive, overweight and have high chances of suffering from obesity. However, more men than women 
tend to suffer from high blood pressure (World Health Statistics Report, 2010). Despite these statistics, Kenyans are not getting screened for lifestyle diseases despite their increasing prevalence (Ireri, 2012). This is in contrast to the developed world where early diagnoses and cheap medication have reduced the mean blood pressure among the population, in turn reducing the mortality rates (Alwan, 2010).

It is due to the adverse effects of non-communicable diseases that organizations are adopting corporate wellness programmes (Davis et al., 2005; Divine, 2006; Kocakulah\&Powers, 2015, Hall, 2014; Buck Consultants, 2009; Keay, Macdonald, Durand, Csiernik, \&Wild, 2010). The emphasis on corporate wellness programmes in preventing ill-health has brought positive benefits to individuals and organizations. According to the National Institute for Health Care Management (2011), corporate wellness programmes promote physical, emotional, social, spiritual, intellectual, cultural, environmental and occupational "fitness" of the workforce. Healthy employees are happy, motivated, productive, committed, feel valued/ cared for and stay longer with their organizations (Kairu, 2015). Research has established a correlation between employee health and wellbeing and organizational turnover (Lutalo, 2007; Paterson, 2013; Prudential Insurance Company of America, 2012).

Despite the positive outcomes of corporate wellness programmes, many organizations are yet to adopt them due to various reasons (Mattke et al., 2013; Kairu, 2015). First, organizations are grappling with the perceived high costs of implementing the programmes (Spicer, 2015). Second, lack of evidence to link corporate wellness programmes with the anticipated benefits has reduced their uptake (Keay et al., 2010; Buck Consultants, 2009; Gyster, 2013; Cancelliere, Cassidy, Ammedolia \&Côté, 2011). Third, other corporations cite lack of financial and human resources necessary for the smooth running of the programmes. Fourth, many companies have not prioritized employees' wellness in their day to day operations (Migliaccio, 2007). Fifth, some organizations have not implemented corporate wellness programmes out of fear that the programmes would contravene employees' privacy and anti-discrimination laws (Stonehouse, 2014; Greengard, 2014). Finally, other companies have implemented some selected corporate wellness programmes with certain categories of employees left out of the programmes (Ngeno\&Muathe, 2014).

\section{LITERATURE REVIEW}

\subsection{Corporate wellness programmes}

These are programmes initiated and sponsored by the employer in order to improve the health and well-being of employees and their families (Berry, Mirabito \&Baun 2010; Ngeno\&Muathe, 2014; Prudential Insurance Company of America, 2012). Corporate wellness programmes focus on addressing specific behaviours and health risk factors such as poor nutrition, physical inactivity, stress, obesity, smoking, infectious diseases/ HIV AIDS, work-life issues, depression, tobacco use, frequent alcohol consumption, fatigue and chronic diseases (Griffin, 2015; Investopedia, 2015).These unhealthy lifestyles have increased the prevalence of chronic diseases such as HIV/AIDS, diabetes, heart disease, asthma, cancer and chronic pulmonary conditions. Poor lifestyles result to serious and expensive health problems, decreased quality of life, premature death and disability and negatively affect employees' performance due to absenteeism and presenteeism (Buck Consultants, 2009; Mattke, 2013; Aspen Publishers, 2011).

Corporate wellness programmes aim at changing unhealthy behaviours and modifying health risk factors. Consequently, the programmes should prioritize on prevention of ill-health rather than the treatment of chronic conditions (Tuwai et al., 2015). Corporate wellness programmes help in maintaining healthy behaviours. The programmes create and raise employees' level of wellness, educate and offer incentives to reinforce healthy lifestyles among employees and their families. Corporate wellness programmes aim at mininimizing the incidence and severity of chronic illnesses. The programmes are often merged with chronic disease management programmes to boost employees' healthy lifestyle support (Buck Consultants, 2009). Corporate wellness programmes help in promoting healthy lifestyles, maintaining or improving health, and preventing or delaying the onset of disease through lifestyle management (Schoenman, 2011; Aspen Publishers, 2011). Corporate wellness programmes should focus on provision of health education, identification of potential health risks factors and promotion of positive health behaviour changes (MetLife, 2013; Hall, 2014; Mattke et al., 2013). A successful corporate wellness programme should essentially address the total wellbeing of the individual, encompassing emotional, social, spiritual, intellectual, physical, financial, career and supportive environments at work, home and in the community (Schoenman, 2011; Seligman, 2005).

\subsection{Types of Corporate wellness programmes}

Corporate wellness programmes are designed to address specific health-related challenges which vary from one geographical region to another and as determined by specific organizational objectives (Buck Consultants, 2009). According to Divine (2006), comprehensive corporate wellness programmes should include:

\subsubsection{Health screenings programmes}

Health screenings are medical tests used to identify hidden health problems among the employees. The screenings are performed by conducting blood, urine, x-rays and ultra sounds. Employees are screened for blood cholesterol, blood pressure, obesity, diabetes mellitus, colorectal cancer, hepatitis B, liver cancer, tuberculosis, sexually transmitted diseases, cervical and breast cancer, osteoporosis and prostate cancer. According to Health Promotion Board (2004), when a health condition is detected early, individuals are able to 
receive early treatment in order to avoid more complications, suffering and death.

\subsubsection{Education programmes}

Education programmes provide employees with information in order to enable them to embrace a healthier lifestyle. The programmes disseminate information about healthy lifestyles through pamphlets, newsletters, emails or websites. Educational programmes may be offered by organizing workshops focusing on diets, exercise, smoking cessation and prevention of illness. These programmes foster employees' level of awareness on issues that may affect their health and wellbeing.

\subsubsection{Physical Fitness programmes}

Physical fitness programmes help employees to access exercise equipment, facilities and classes. They include encouraging walking and cycling exercises, on-site exercise facilities such as gyms or reduced-cost access to local wellness centres. These programmes enhance employees' physical fitness, in turn preventing non-communicable diseases and avoidable disabilities.

\subsubsection{Employee Assistance Programmes (EAP's)}

Employee Assistance Programmes (EAP's) are work-based programmes that aim at addressing emotional, mental and psychological well-being of employees and their families. The programmes prevent, identify and solve work and non-work related issues that may affect employees' well-being and job performance (Dunkin, 2008; Benavides\&David, 2010). These issues include stress, drug and substance abuse, depression, fatigue, sleep problems, mental health stigma, absenteeism, presenteeism, lifestyle risks, physical and chronic conditions (National Business Group on Health, 2008).

\subsection{Benefits of corporate wellness programmes}

According to Kocakulah\& Powers (2015), corporate wellness programmes have significant benefits to employees, organizations and the community at large. These benefits include:

\subsubsection{Reduction of healthcare costs and insurance claims}

Employees' poor health affects the financial performance of a business negatively (Hanson, 2009; Controller's Report, 2012; Paterson, 2013; Prudential Insurance Company of America, 2012). Unhealthy employees are less productive and companies incur high costs in the course of their treatment. The employer ends up absorbing the high medical costs and low job performance which affects the competitive ability of the business (Independence Blue Cross, 2013; Anderson\& Niebuhr, 2010; Prudential Insurance Company of America, 2012; Kallinowsky \& Simiyu, 2011; Aspen Publishers, 2011). Corporate wellness programmes reduce medical costs and health care use (Burd, 2014; Herbert, 2011; Lovewell, 2009; Perkins, 2009; Hall, 2005; Lejeune, 2013; Kocakulah\&Powers, 2015). Organizations with corporate wellness programmes benefit from reduced employees' death claims (Lutalo, 2007).

2.3.2 Reduction of employees' absenteeism and
presenteeism

Employees' poor health and personal issues increase the time spent out of work (Aspen Publishers, 2011). Absenteeism and presenteeism lead to reduced job performance and indirect medical costs such as disability claims (Controller's Report, 2012; Independence Blue Cross, 2013; Prudential Insurance Company of America, 2012; MetLife, 2013). Corporate wellness programmes promote a healthy and committed workforce; in turn reducing absenteeism, presenteeism and employee sick offs (Perkins, 2009; Lovewell, 2009; Rogers Publishing Company Limited, 2013; Vogel, 2015; Seligman, 2005; MetLife, 2013).

\subsubsection{Increased job performance and employee efficiency}

Employees' poor health and other personal problems lead to reduced individual and organizational performance (Blerbower, 2013; Perkins, 2009). Workers with chronic health conditions usually exhibit poor performance (Prudential Insurance Company of America, 2012; Aspen Publishers, 2011; Anderson\& Niebuhr, 2010). On the contrary, healthy employees exhibit greater energy levels, better focus, better resiliency and a more positive outlook to life; which leads to enhanced job performance (National Park Service, 2014; Patton, 2015; Controller's Report, 2012; Paterson, 2013). Corporate wellness programmes promote shareholder value due to increased job performance and efficiency at work (Hanson, 2009; Benavides \&David, 2010; Perkins, 2009; Kocakulah\&Powers, 2015).

\subsubsection{Health-related behaviour and health status}

Corporate wellness programmes lead to a more knowledgeable and health conscious workforce. This enhances employees' awareness and confidence in wellness issues (Patton, 2015; Stonehouse, 2014). As a result, employees develop significant and meaningful improvements in health risk behaviours (such as alcohol use, fat intake, physical activity, tobacco use and use of seat belts); improvement of biometric outcomes (blood pressure and cholesterol); reduction of health risks and use of health care services. Corporate wellness programmes have a positive impact on health-related behaviour and lead to health risks reduction among programme participants (Rombel, 2007; Mattke, 2013; Rogers Publishing Company Limited, 2013; Schoenman, 2011).

\subsubsection{Substantial return on investment (ROI)}

The positive measurable return on investment (ROI) of corporate wellness programmes has challenged employers to adopt the programmes in order to encourage employees to make healthy lifestyle changes (Hall, 2005; Valet, 2015; Lejeune, 2013). Corporate wellness programmes can achieve cost savings and produce significant returns on investment 
such as reduction of workers' compensation claims which may arise from work-related injuries, reduced recruitment costs and costs related to induction of new employees (Perkins, 2009; Benavides\&David, 2010 ; Aspen Publishers, 2011; Rogers Publishing Company Limited, 2013; Anderson\& Niebuhr, 2010).

\subsubsection{Increased safety and reduction of work- related accidents}

Job-related injuries can be minimized through the adoption of corporate wellness programmes (Rombel, 2007, Stonehouse, 2014). This is achieved when organizations incorporate safety standards and procedures in their work place (Lutalo, 2007; Keay et al., 2010; Seligman, 2005; Perkins, 2009).

\subsubsection{Long -term benefits of corporate wellness programmes}

Corporate wellness programmes have the potential to strengthen organizational culture, values, mission and build employees' loyalty, pride, trust and commitment to the company. When implemented properly, the programmes can build deep bonds between employees and the organizations they work for (Berry et al., 2010; Vernon, 2010).

\subsubsection{Improvement of job satisfaction}

According to Controller's Report (2012), corporate wellness programmes enable workers to interact and develop relationships that build a stronger community and increase job satisfaction. Adopting corporate wellness programmes leads to reduced turnover rates and increased job satisfaction (Independence Blue Cross, 2013; Vernon, 2010; Diamond, 2013). Employees with enhanced morale are more likely to be productive due to increased sense of responsibility to the employer and improved job satisfaction (Stonehouse, 2014). There exists a direct correlation between worker satisfaction and client satisfaction (Lutalo, 2007)

\subsubsection{Improvement of employees' engagement}

When a company demonstrates commitment to its workforce, employees reciprocate by being more committed to the company. Engaged employees are meticulous, motivated and perform exceptionally. Organizations with engaged employees record lower absenteeism, lower turnover and high job performance (Diamond, 2013; Kalish, 2014). In contrast, disengaged employees have low career well-being. The health risks of disengaged employees increase the number of days they are absent from their job (Independence Blue Cross, 2013).

\subsubsection{Enhanced employee attraction and retention}

Corporate wellness programmes are a determining factor for potential employees when choosing an employer. Workers from companies with good corporate wellness programmes stay with their organizations for a long time. Organizations with highly effective corporate wellness programmes report significantly lower voluntary attrition as compared to companies with less effective corporate wellness programmes (Berry et al., 2010; Vernon, 2010; Rogers Publishing Company Limited, 2013; Patton, 2015; Valet, 2015; Prudential Insurance Company of America, 2012). According to Lutalo (2007), corporate wellness programmes reduce the rate of mortality in organizations.

\subsubsection{Maintenance of worker ability}

According to Cancelliere et al. (2011), worker ability refers to employees' physical, psychological and social capacity to work and is determined by employees' health and contents of their work. Corporate wellness programmes help in reducing employees' absenteeism occasioned by sickness or disability. The programmes reduce stress, burnout and enhance employees' well-being (Churchill et al., 2014; Kocakulah\&Powers, 2015; Carlson, 2014; Abebe, 2015). Corporate wellness programmes lead to the development of team-building skills (Buck Consultants, 2009; Seligman, 2005).

\subsubsection{Promotion of corporate image/ brand}

Corporate wellness programmes enhance organizational reputation and establish the company as the Employer-ofChoice (Burd, 2014; Valet, 2015). In emerging economies, a high value is placed on employers who support health (MetLife, 2013; Anderson\& Niebuhr, 2010). Implementing a corporate wellness programme communicates to the employees that they are cared for by the organization. This fosters good will and employee recruitment and retention (Hanson, 2009; Lovewell, 2009; Rogers Publishing Company Limited, 2013; Meyer, 2009).

\subsubsection{Social-community responsibility}

Corporate wellness programmes enhance the quality of life within the organization and in the surrounding communities (Tongoi, 2013). For instance, the Kenya Serena Hotel's corporate wellness programme aims at reducing the incidences of injuries, communicable and lifestyle diseases within the company and in the surrounding communities (Lutalo, 2007).

\subsection{Corporate wellness programmes, Employee efficiency and Job Performance}

Employees' poor health and other personal problems lead to reduced individual and organizational performance (Atkinson, 2004; Blerbower, 2013; Kallinowsky\& Simiyu, 2011 and Perkins, 2009). It is reported that workers with chronic health conditions are more prone to reduced job performance (Prudential Insurance Company of America, 2012; Aspen Publishers, 2011; Anderson\& Niebuhr, 2010). On the contrary, healthy employees have greater energy levels, better focus, better resiliency and a more positive outlook to life; resulting to increased job performance ("National Park Service", 2014; Tuwai et al., 2015; Kairu, 2015; Paterson, 2013). According to Buck Consultants (2009), improving job performance and reducing "presenteeism" is a common 
objective for the adoption of corporate wellness programmes worldwide. It is believed that implementing corporate wellness programmes promotes shareholder value as a result of increased job performance and efficiency at work (Hanson, 2009; Munyi, 2012; Perkins, 2009).

\subsection{Theoretical Framework}

Two (2) key theories of human motivation informed the theoretical framework for this study. These theories include Maslow's hierarchy of needs theory and Herzberg's dualfactor theory.

\subsubsection{Maslow's Hierarchy of Needs Theory}

Abraham Maslow identified five (5) categories of human needs arranged in a hierarchical order. These needs include physiological, security, social, self-esteem and selfactualization needs. According to Maslow, individuals should first meet the basic needs before they are motivated to satisfy the higher level needs. This is because if the basic needs are not met, employees' behaviour will be geared towards the satisfaction of these basic needs. After the satisfaction of physiological needs, employees would be motivated to satisfy security needs and this would continue until self-actualization needs are met.

Physiological needs are at the foundation of the pyramid and include basic needs necessary for survival such as food, clothing and shelter. The second level of needs is referred to as safety and security needs. These needs are expressed through a desire for safety in one's job, health and family. These needs are usually attained when employees' fears and anxieties are low. In the third level of needs, employees work towards the attainment of love and belonging. Employees strive to establish job relationships by building friendships, love and intimacy in order to experience acceptance from other people. The fourth level of needs comprises of selfworth and self esteem needs. Employees seek to attain selfworth by being accepted and valued by others. At the apex of the pyramid is the need for self- actualization. This refers to a person's desire to become everything he/she would like to become by making use of his/her full potential, capacities and talents (Martin\& Joomes, 2007; Ngeno\& Muathe, 2014).

\subsubsection{Herzberg's Dual-factor Theory}

Herzberg came up with two factors that explain motivation at the work place, that is, motivational factors and hygiene factors. Intrinsic factors (motivators) come from within the individual and enhance job satisfaction when present. When motivational factors are met, employees would be motivated and perform higher. Motivational factors include the need for achievement, interest in the task, responsibility, recognition, autonomy, challenge, growth, advancement and other intrinsic aspects. On the other hand, hygiene (maintenance) factors come from outside the individual, enhance the work environment when present and lead to de-motivation when absent. As such, absence of hygiene factors would lead to employee dissatisfaction. Examples of hygiene factors include salary, working conditions, status, company policies and administration, supervision-technical and interpersonal relationships-supervision (Ozguner\& Ozguner, 2014; Ngeno\& Muathe, 2014). According to Herzberg, in order for employees to be motivated, both factors, that is motivational and hygiene factors have to be fulfilled.

\subsection{Conceptual Framework}

The research conceptualized that employee efficiency and job performance; being the dependent variables, are influenced by corporate wellness programmes, the study's independent variable as shown in figure 2.1.

Figure 2.1: Conceptual Framework

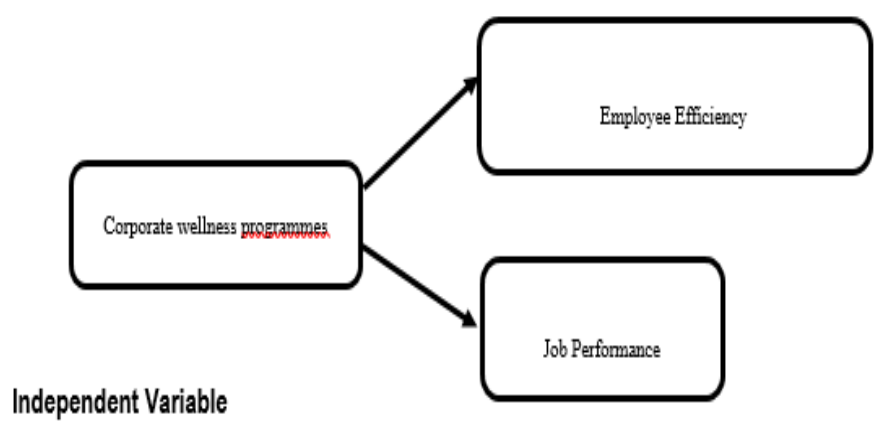

Dependent Variables

\section{RESEARCH METHODOLOGY}

Quantitative research design was employed for this study. The survey method was used in the study by use of questionnaires. The Job Performance Scale developed by Goodman\& Svyantek (1999) was incorporated into the questionnaire. Stratified sampling procedure was used to identify the final sample that consisted of thirty-two (32) middle level executives working in Standard Group Limited.

The reliability of the Instrument of the Job Performance Scale has been ascertained using Cronbach's Alpha Coefficient, item total correlations and Inter-Scale correlations. Except for few items, almost all items have values above 0.60 , thus proving the reliability of the scale. On the other hand, the validity of the scale has been ascertained using Exploratory and Confirmatory Factor Analysis. Convergent validity has been determined using factor loadings equal to 0.50 or greater than were considered significant. Results of Principal Component Analysis showed that factor loading ranged from 0.60 to 0.94 . Likewise, the communalities also ranged from 0.65 to 0.87 . The Kaiser-Meyer-Olkin measure of sample adequacy was within range of 0.82. Similarly, the total Eigen values for all the 25 items was above 01 (Yusoff, Ali\& Khan, 2014). Construct validity was ascertained through Confirmatory Factor Analysis, with Maximum Likelihood Estimation. One factor model had poor fit, i.e. $\mathrm{X} 2 / \mathrm{df}=3.17$, RMSEA $=0.123$, CFI $=0.68$ and GFI $=0.61$. The two factor 
model showed relatively good fit in comparison to one factor model, i.e. $\mathrm{X} 2 / \mathrm{df}=2.41$, RMSEA $=0.088, \mathrm{CFI}=0.77$ and $\mathrm{GFI}=0.81$. While the analysis showed that the three factor model was much more consistent with data and showed better fit in comparison to both model one and two, i.e. $\mathrm{X} 2 / \mathrm{df}=1.83$, RMSEA $=0.098, \mathrm{CFI}=0.88$ and GFI $=0.92$. Therefore, the three factor model was accepted as it more parsimonious than the rest of models (Yusoff, Ali\& Khan, 2014 p.39-40). The research instrument was piloted before data collection to ensure face validity (Weiner, 2007; Simon, 2011). This is because the instrument was changed from a supervisor assessment scale into a self-assessment scale. In addition, piloting the questionnaire helped in contextualizing the instrument since it was previously used in the Middle East.

The data collected was analysed using the Statistical Package for the Social Sciences (SPSS). The demographic information of the participants was processed and calculated in percentages in order to provide a general overview of the respondents. The analysis focused on the respondents' gender, age, marital status, level of education, the period the respondent had worked in Standard Group Limited, religious affiliation, the average time the respondent takes from home to work and back on any given work day and the respondent's nationality. An analysis was conducted in order to establish whether Standard Group offered corporate wellness programmes. Specifically, the statistical analysis focused on ascertaining whether the company offered physical fitness, smoking cessation, alcohol and substance abuse, stress management and health education programmes to its employees. This analysis was followed by calculating the frequency of the respondents' participation in the above mentioned programmes. The data was tabulated and presented in tables, frequencies and percentages. A further data analysis was conducted to ascertain the participants' efficiency ratio and job performance as informed by the respondents' annual efficiency appraisal and subjective evaluation of their job performance as guided by the research instrument. Data processing and analysis was concluded by analysing the association between the independent and dependent variables. This was done by comparing the respondents' participation in each of the corporate wellness programmes, their efficiency and job performance. This was followed by a comparison to establish the association between the respondent's participation in the overall corporate wellness programmes, their efficiency and job performance. A bivariate analysis was conducted in order to establish the strength of association between the Independent and dependent variables. The correlation between the independent and dependent variables was calculated using Pearson-Product Moment Correlation Coefficient.

\section{DATA ANALYSIS}

The data collected was analysed as per the Research objectives. $78.2 \%$ of the respondents agreed that Standard Group Limited offered Corporate wellness programmes such as Physical Fitness Programme, Smoking Cessation
Programme, Alcohol and Substance Abuse Rehabilitation Programme, Stress Management Programme and Health Education Programme

\subsection{Participation in corporate wellness programmes and employees' efficiency}

The study found out that there was a strong correlation at .068 (sig. 0.71) between participation in corporate wellness programmes and employees' efficiency as shown on table 4.1.1

\begin{tabular}{|c|c|c|c|}
\hline \multicolumn{4}{|c|}{ Table 4.1.1: Participation in corporate wellness programmes and employees' } \\
efficiency
\end{tabular}

This means that the Corporate wellness programmes adopted by Standard Group Limited have enhanced employees' efficiency at the work place. According to Kocakulah\&Powers (2015), Corporate wellness programmes have been associated with productivity gains such as reduced errors, improved efficiency and better decision making.

\subsubsection{Participation in Corporate wellness programmes and Job Performance}

The research found out that there was no significant relationship at .219 (sig. 0.229) between participation in corporate wellness programmes and job performance as shown on table 4.12.

\begin{tabular}{|c|c|c|c|}
\hline \multicolumn{4}{|c|}{$\begin{array}{l}\text { Table 4.1.2: Participation in corporate wellness programmes and job } \\
\text { performance }\end{array}$} \\
\hline & & $\begin{array}{c}\text { Participation in } \\
\text { the corporate } \\
\text { wellness } \\
\text { activities }\end{array}$ & $\begin{array}{l}\text { Total job } \\
\text { performance } \\
\text { score }\end{array}$ \\
\hline \multirow{3}{*}{$\begin{array}{c}\text { Participation in } \\
\text { selected } \\
\text { corporate } \\
\text { wellness } \\
\text { activities }\end{array}$} & $\begin{array}{c}\text { Pearson } \\
\text { Correlation }\end{array}$ & 1 & .219 \\
\hline & Sig. (2-tailed) & & .229 \\
\hline & $\mathrm{N}$ & 32 & 32 \\
\hline \multirow{3}{*}{$\begin{array}{l}\text { Total Job } \\
\text { performance } \\
\text { score }\end{array}$} & $\begin{array}{c}\text { Pearson } \\
\text { Correlation } \\
\end{array}$ & .219 & 1 \\
\hline & Sig. (2-tailed) & .229 & \\
\hline & $\mathrm{N}$ & 32 & 32 \\
\hline
\end{tabular}


Therefore, we can infer that even though the job performance of the respondents was commendable, it could have been influenced by other factors other than participating in Corporate wellness programmes. Research has established that certain individual and organizational factors affect the job performance of the workforce. These factors include job stress, motivation, communication, financial rewards and trainings (Muda, Rafiki \& Harahap, 2014; Iqbal, Latif, Ijaz\& Mushtaq, 2015).

\subsection{Testing of the Hypotheses}

The research hypotheses for the study were tested as follows:

\subsubsection{Ho: Standard Group Limited does not offer corporate wellness programmes}

$78.2 \%$ of the respondents agreed with the statement that "Standard Group Limited offers corporate wellness programmes". In response to statements regarding individual corporate wellness programmes, that is, physical fitness programme, smoking cessation programme, alcohol and substance abuse rehabilitation programme, stress management programme and health education programme; $80.02 \%$ of the respondents agreed that the programmes were offered in standard Group Limited. The above hypothesis was negated since majority of the respondents agreed that Standard Group Limited offered corporate wellness programmes as shown on table number 4.9 , table 4.10 , table 4.11 , table 4.12 , table 4.13 and table 4.14 .

\subsubsection{Ho: There is no significant relationship between corporate wellness programmes and employees' efficiency}

The research found a strong relationship at .068 (sig. 0.71) between corporate wellness programmes and employees' efficiency as shown on table 4.15. This means that the efficiency of the middle level executives in Standard Group Limited had increased as a result of their participation in corporate wellness programmes. Therefore, the above hypothesis was negated based on the findings of the study.

\subsubsection{Ho: There is no significant relationship between corporate wellness programmes and job performance}

The study found no significant relationship at .219 (sig. 0.229) between corporate wellness programmes and job performance as shown on table 4.16. This means that the job performance of the middle level executives in Standard Group Limited was not affected by their participation in corporate wellness programmes. Therefore, this hypothesis was confirmed as true based on the findings of the research.

\section{DISCUSSION AND CONCLUSION}

The study established that Standard Group Limited offers Corporate wellness programmes such as physical fitness programme, smoking cessation programme, stress management programme, alcohol and substance abuse rehabilitation programme and health education programme. Previous studies had hinted on the association between corporate wellness programmes, employees' efficiency and job performance. However, no previous research had managed to generate empirical data in order to link corporate wellness programmes, employees' efficiency and job performance (Keay et al., 2010). This study found a strong relationship between corporate wellness programmes and employees' efficiency. However, the research found no significant relationship between corporate wellness programmes and job performance.

This study has contributed significantly to the understanding that corporate wellness programmes increase employees' efficiency. As such, the research has generated empirical evidence in order to link corporate wellness programmes with employees' efficiency. In addition, the study has increased the number of studies done globally and in Kenya on corporate wellness programmes and how they relate to various organizational outcomes. The study has contributed to the ongoing debate on the importance of employee wellbeing in organizations and the community at large.

The study recommends that organizations should consider providing health education programmes in the work place in order to equip the workforce with the requisite knowledge on the importance of participating in corporate wellness programmes. Secondly, organizations offering corporate wellness programmes should consider conducting regular sensitizations in order to improve the awareness among the workforce on the programmes being offered in the organization. Thirdly, organizations should create a culture for health in the workplace by supporting employees' wellness through written and unwritten law. All employees in organizations should support an organizational culture that enhances the health and wellbeing of all employees in the work place (Institute for Health and Productivity studies, 2016). Fourth, organizations offering corporate wellness programmes should provide strong, visible and active support. Fifth, organizations offering corporate wellness programmes should consider using incentives to increase employees' participation. The incentives include free gym memberships, prizes and other recognition such as extra time off for each wellness target met (Kocakulah\&Powers, 2015). Sixth, institutions should consider developing partnerships and social support networks with the surrounding communities. This is important since partnerships enhance social support for healthy lifestyles. Establishing partnerships reinforces health messages by engaging the whole family in community health activities. Partnerships help in establishing social networks to support healthy behaviours. Some examples of social networks that can be embraced by organizations include walking clubs, cycling groups and group exercises. Seven, organizations should consider offering holistic corporate wellness programmes in order to maximize the benefits. This can be achieved by use of integrated wellness programmes that address physical, emotional, intellectual, economic, social and spiritual aspects of the employees. Eight, participation in corporate wellness programmes should be fostered by making 
use of what appeals to the employees based on their preferences, interests and health needs. This can be achieved by designing the corporate wellness programmes with the interests of the employees in mind. Finally, organizations should consider monitoring employees' progress towards the attainment of the agreed wellness objectives. It is through regular monitoring that organizations will be in a position to identify the weaknesses in the programmes and improve them in order to create healthy employees and organizations.

The research has ascertained that there is scarcity of studies on Corporate wellness programmes in Kenya. This is despite the apparent benefits the programmes have on individual employees and organizations. Consequently, it is suggested that future research should be conducted on the relationship between corporate wellness programmes and other organizational outcomes such as reduction of health care costs, employee commitment and engagement, health improvement, health risk reduction, reduction of business costs, reduction of work-related accidents, organizational culture, turnover and job satisfaction, attraction and retention, employee wellbeing, corporate image and social-community responsibility.

\section{REFERENCES}

[1] Abebe, N. (2015). The Value of Workplace Wellness Programs Employee Benefit Plan Review, 7-9. Retrieved from http://web.b.ebscohost.com/ehost/pdfviewer/pdfviewer?vid=18\&si $\mathrm{d}=\mathrm{f} 0090 \mathrm{c} 22-9 \mathrm{c} 94-46 \mathrm{ef}-\mathrm{af05}-$ 8d0b78ac46bd\%40sessionmgr $111 \&$ hid $=118$ on 25.1 .16

[2] Alwan, A. (2010). Global status report on noncommunicable diseases. World Health Organization, 1-176. Retrieved from http://www.who.int/nmh/publications/ncd report_full_en.pdf on 26.1.16

[3] Anderson, D., \&Niebuhr, S. (2010). Get Your Workforce in Top Shape. Benefits\& compensation Digest, 28-31. Retrieved from https://vpn.uonbi.ac.ke/proxy/http/web.b.ebscohost.com/ehost/pdf viewer/pdfviewer?vid=34\&sid=22fe7785-04b8-44c1-908058879053ad69\%40sessionmgr113\&hid $=118$ on 17.10 .15

[4] Anumaka, B., \&Ssemugenyi, F. (2013). Gender and WorkProductivity of Academic Staff in Selected Private Universities in Kampala City, Uganda. IMPACT: International Journal of Research in Business Management (IMPACT: IJRBM), 1(3), 29$36 . \quad$ Retrieved from https://www.google.com/?gws_rd=sslm.bayt.com\#q=relationship+ between+gender+and+work+performance on 12.9.15

[5] Arkkelin, D. (2014). Using SPSS to Understand Research and Data Analysis. Psychology Curricular Materials, Book 1, 1-195. Retrieved from http://scholar.valpo.edu/psych oer/1 on 1.11.15

[6] Aspen Publishers. (2011). Study Examines Impact of Medication

[7] Adherence, Multiple Chronic Diseases, and Health Risks in the Workplace. Managed Care, 24(19), 1-5. Retrieved from https://vpn.uonbi.ac.ke/proxy/http/web.b.ebscohost.com/ehost/pdf viewer/pdfviewer?vid=36\&sid=22fe 7785-04b8-44c1-908058879053ad69\%40sessionmgr113\&hid=118 on 17.10 .15

[8] Atkinson, W. (2004). Why It Pays to Support Employee Health and Fitness Programs. Heart Smart, 34-43. Retrieved from https://vpn.uonbi.ac.ke/proxy/http/web.b.ebscohost.com/ehost/pdf viewer/pdfviewer?vid=8\&sid=22fe7785-04b8-44c1-908058879053ad69\%40sessionmgr113\&hid=118 on 17.10 .15

[9] Australian Health Promotion Association. (2015). What is Health Promotion? Retrieved from http://www.healthpromotion.org.au/component/content/article/3general/92-what-is-health-promotion on 7.9 .15
[10] Benavides, A. \&David, H. (2010). Local Government Wellness Programs: A Viable Option to Decrease Healthcare Costs and Improve Productivity. Public Plan, pp. 291-306. Retrieved from https://vpn.uonbi.ac.ke/proxy/http/web.b.ebscohost.com/ehost/pdf viewer/pdfviewer?vid=48\&sid=7d9dc763-ab82-4271-993ce8daa4373873\%40sessionmgr102\&hid=102 on 30.1.16

[11] Berry, L., Mirabito, A., \&Baun, W. (2010). What's the Hard Return on Employee Wellness Programs? Harvard Business Review, 1-10. Retrieved from http://www.stepsafari.com/getfile/PDFs\%20Public/Whats-theHard-Return-on-Employee-Wellness-Programs-Harvard-BusReview.PDF on 21.10.15

[12] Bloom, D.E., Cafiero, E.T., Jané-Llopis, E., Abrahams-Gessel, S., Bloom, L.R., Fathima, S., Weinstein, C. (2011). The Global Economic Burden of Noncommunicable Diseases. Geneva: World Economic Forum, 1-48. Retrieved from http://www3.weforum.org/docs/WEF_Harvard_HE_GlobalEcono micBurdenNonCommunicableDiseases 2011.pdf on 3.2.16

[13] British Medical Journal. (2011). How should we define health? Analysis, 343:d416. DOI: 10.1136/British Medical Journal.d4163

[14] Buck Consultants. (2009). A Global Survey of Health Promotion and Workplace Wellness Strategies. Working Well. Retrieved from

https://www.google.com/?gws rd=ssl\#q=corporate+wellness+pro grams+europe\&start $=10$ on 10.8 .15

[15] Buck Consultants. (2009). Working Well: A Global Survey of Health Promotion and Workplace Wellness Strategies; Executive Summary. Global Wellness Survey, 1-8. Retrieved from https://www.worldatwork.org/waw/adimLink?id=36309 10.8.15

[16] Burd, J. (2014). Well Done, Spotlight Employee Wellness, 15-19. Retrieved https://vpn.uonbi.ac.ke/proxy/http/web.b.ebscohost.com/ehost/pdf viewer/pdfviewer?vid=41\&sid=7d9dc763-ab82-4271-993ce8daa4373873\%40sessionmgr102\&hid $=102$ on 30.1 .16

[17] Business Dictionary. (2016). Employee. Retrieved from http://www.businessdictionary.com/definition/employee.html on 5.2.16

[18] Business Directory. (2016). Performance. Retrieved from http://www.businessdictionary.com/definition/performance.html on 25.1 .16

[19] Butler, K. (2015). Proper Wellness Takes Balance, 28-48. Retrieved from http://web.b.ebscohost.com/ehost/pdfviewer/pdfviewer?vid=13\&si $\mathrm{d}=\mathrm{f} 0090 \mathrm{c} 22-9 \mathrm{c} 94-46 \mathrm{ef}-\mathrm{af05}-$ 8d0b78ac46bd\%40sessionmgr111\&hid=118 on 25.1 .16

[20] Cancelliere, C., Cassidy, J., Ammendolia, C., \&Côté, P. (2011). Are workplace health promotion programs effective at improving presenteeism in workers? A systematic review and best evidence synthesis of the literature. BMC Public Health, 11(395), 1-11. DOI: 10.1186/1471-2458-11-395

[21] Carlson, J. (2014). The Evolution of Workplace Wellness Programs, 1-3. Retrieved from http://web.b.ebscohost.com/ehost/pdfviewer/pdfviewer?vid=12\&si $\mathrm{d}=\mathrm{f} 0090 \mathrm{c} 22-9 \mathrm{c} 94-46 \mathrm{ef}-\mathrm{af05}$ 8d0b78ac46bd\%40sessionmgr111\&hid $=118$ on 25.1 .16

[22] Churchill, S., Gillespie, H. \&Herbold, N. (2014).The Desirability of Wellness

[23] Program and Incentive Offerings for Employees. Wellness Incentives, 48-57. Retrieved from http://web.b.ebscohost.com/ehost/pdfviewer/pdfviewer?vid=5\&sid $=$ f0090c22-9c94-46ef-af058d0b78ac46bd\%40sessionmgr111\&hid=118 on 25.1 .16

[24] Clifton, S. (2012). Ethical Issues in Quantitative Research. Retrieved from http://www.lse.ac.uk/LSEHealthAndSocialCare/pdf/Ethics\%20Wo rkshop/Clifton.pdf on 24.11.15

[25] Connect Workplace White Paper. (2015). Convince Us Why a Wellness Program Is Worth the Investment. Mind Body, 1-6. Retrieved from https://www.mindbodyonline.com/connectworkplace/sites/mindbodyonline.com.connect 
workplace/files/whitepapers/MINDBODYConnectWorkplaceConvinceYourExecsWhyaWellnessProgramisWorththeInvestment .pdf on 8.2.16

[26] Controller's Report. (2012). With Health Care Costs Rising, Wellness Programs Offer Much Needed Savings. HR: Benefits/ Health/ Compensation Costs, 5-6. Retrieved from https://vpn.uonbi.ac.ke/proxy/http/web.b.ebscohost.com/ehost/pdf viewer/pdfviewer?vid=47\&sid=7d9dc763-ab82-4271-993ce8daa4373873\%40sessionmgr102\&hid=102 on 30.1 .16

[27] Davis, K., Collins, S., Doty, M., Ho, A. \&Holmgren, L. (2005) Health and Productivity among U.S. Workers. Issue Brief, 1-10. Retrieved

from http://www.commonwealthfund.org/usr_doc/856_Davis_hlt_produ ctivity_USworkers.pdf on 14.10 .15

[28] Department of Health. (2010). Our Health and Wellbeing Today. HM Government, 1-68. Retrieved from https://www.gov.uk/government/uploads/system/uploads/attachme nt data/file/215911/dh 122238.pdf on 9.2.16

[29] Diamond, P. (2013). Wellness in the New Economic World. Special Report: Employee Matters, 64-70. Retrieved from https://vpn.uonbi.ac.ke/proxy/http/web.a.ebscohost.com/ehost/pdf viewer/pdfviewer?vid=8\&sid=e0c44563-99df-4d71-b155$06 \mathrm{c} 7 \mathrm{~d} 2 \mathrm{cc} 06 \mathrm{a} 1 \% 40 \mathrm{sessionm}$ r 4005 \&hid $=4107$ on 25.2 .16

[30] Divine, R. (2006). Determinants of Small Business Interest in Offering a Wellness Program to Their Employees, Health Marketing Quarterly, 22:3, 43-58. DOI: 10.1300/J026v22n03_04

[31] Dunkin, M. (2008).Caring for Body and Mind. Body-Mind Connection, 52-53. Retrieved from https://vpn.uonbi.ac.ke/proxy/http/web.b.ebscohost.com/ehost/pdf viewer/pdfviewer?vid=29\&sid=22fe 7785-04b8-44c1-908058879053ad69\%40sessionmgr113\&hid=118 on 17.10 .15

[32] Employee Assistance Professional Association of Australia. (2009).What is an Employee Assistance Program? Retrieved from http://www.eapaa.org.au/ on 8.9.15

[33] Evans, D., Gruba, P., \&Zobel, J. (2014). How to Write a Better Thesis. Switzerland: Springer. Swansea University. (2015). Referencing According to the APA $6^{\text {th }}$ Style. Retrieved from https://blackboard.swan.ac.uk/bbcswebdav/institution/LibraryISS Resources/Referencing\%20Guides/Full\%20APA\%20referencing \%20guide.pdf on 14.12 .15

[34] Green, C., Jegadeesh, N., \&Tang, Y. (2009). Gender and Job Performance: Evidence from Wall Street. Financial Analysts Journal, 65(6), 1-15. Retrieved from http://www.bus.emory.edu/cgreen/docs/Green,Jegadeesh,Tang F AJ2009.pdf on 12.9.15

[35] Greene, J. (2011). Employee Wellness Proves its Worth, Cover Story Workforce, 8-12. Retrieved from https://vpn.uonbi.ac.ke/proxy/http/web.b.ebscohost.com/ehost/pdf viewer/pdfviewer?vid=36\&sid=7d9dc763-ab82-4271-993ce8daa4373873\%40sessionmgr102\&hid=102 on 30.1 .16

[36] Greengard, S. (2014). Reducing Business Costs with Wellness Programs. Business Source Premier, 1-2. Retrieved from https://vpn.uonbi.ac.ke/proxy/http/web.a.ebscohost.com/ehost/deta il/detail?vid=29\&sid=e0c44563-99df-4d71-b15506c7d2cc06a1\%40sessionmgr4005\&hid=4107\&bdata=JnNpdGU9 ZWhvc3QtbGl2ZQ\%3d\%3d\#AN=98529480\&db=buh on 25.2.16

[37] Griffin, D. (2015). What Is an Employee Wellness Programe? Retrieved from http://smallbusiness.chron.com/employeewellness-program-1349.html on 6.9.15

[38] Gyster, V. (2013). A faster, cheaper way to Wellness programs that work, Employee Benefit News, 56-58. Retrieved from https://vpn.uonbi.ac.ke/proxy/http/web.b.ebscohost.com/ehost/pdf viewer/pdfviewer?vid=42\&sid=7d9dc763-ab82-4271-993ce8daa4373873\%40sessionmgr102\&hid $=102$ on 30.1 .16

[39] Hall, B. (2005). Bona Fide Wellness Programs under HIPAA Journal of Deferred Compensation, 66-70. Retrieved from https://vpn.uonbi.ac.ke/proxy/http/web.b.ebscohost.com/ehost/pdf viewer/pdfviewer?vid=13\&sid=22fe7785-04b8-44c1-908058879053ad69\%40sessionmgr113\&hid=118 on 17.10 .15

[40] Hall, B. (2014). Trends and Best Practices in Global Workplace Wellness.
https://www.google.com/?gws_rd=sslm.bayt.com\#q=Trends+and+ Best+Practices+in+Global+Workplace+Wellness on 10.8 .15

[41] Hanson, W. (2009).Connecting the dots: Financial Wellness, physical Wellness and shareholder value. Employee-Consumer, 20-21. Retrieved from https://vpn.uonbi.ac.ke/proxy/http/web.b.ebscohost.com/ehost/pdf viewer/pdfviewer?vid=9\&sid=22fe 7785-04b8-44c1-908058879053ad69\%40sessionmgr113\&hid=118 on 17.10 .15

[42] Health advocate. (2009). Stress in the Workplace. Meeting the Challenge, 1-19. Retrieved from http://healthadvocate.com/downloads/webinars/stressworkplace.pdf on 15.10 .15

[43] Health and Safety Authority. (2010). Health and Safety Management in Healthcare. Information Sheet, 1-6. Retrieved from

https://www.besmart.ie/fs/doc/Small_Business/Documents/Health _and_Safety_Management_in_Healthcare.pdf on 15.10.15

[44] Health Promotion Board. (2004). Health Screening.1-27.Retrieved from

https://www.moh.gov.sg/content/dam/moh_web/Publications/Edu cational\%20Resources/2006/Health_Screening.pdf on 25.10.15

[45] Herbert, M. (2011). Wellness Programs Reduce Employee Healthcare Costs, Briefings News Update, p.25. Retrieved from https://vpn.uonbi.ac.ke/proxy/http/web.b.ebscohost.com/ehost/pdf viewer/pdfviewer?vid=43\&sid=7d9dc763-ab82-4271-993ce8daa4373873\%40sessionmgr102\&hid=102 on 30.1 .16

[46] Independence Blue Cross. (2013). Employee wellness as a strategic business imperative. Retrieved from https://www.ibx.com/pdfs/employers/employer_resources/wellnes s_whitepapers/wellness_whitepaper_112013.pdf on 21.10.15

[47] Ireri, M. (2012). Kenyans not screening for lifestyle diseases despite their increasing prevalence. Ipsos Synovate, 1-6.Retrieved from

http://www.ipsos.co.ke/spr/downloads/lifestyle_issues/Kenyans_n ot_screening_for\%20_Cancer_Diabetes_High\%20Blood\%20Press ure_despite_their_increasing_prevalence $\% 20 \% 28$ Sep $\% 20 \% 20201$ 2\%29.pdf on 20.8 .15

[48] Investopedia (2015).Wellness Program: 'Definition of 'Wellness Program. Retrieved from http://www.investopedia.com/terms/w/wellness-program.asp on $\underline{8.9 .15}$

[49] Iqbal, A., Latif, F., Ijaz, M.\& Mush taq, H. (2015). Factors Affecting the Employee's Performance: A Case Study of Banking Sector in Pakistan. European Journal of Business and Social Sciences, 4(08), $309-318 . \quad$ Retrieved from http://www.ejbss.com/Data/Sites/1/vol04no08november2015/ejbss -1656-15-factorsaffectingtheemployeesperformance.pdf on 2.12 .2015

[50] Johns, G. (2009). Presenteeism in the workplace: A Review and Research agenda. Journal of Organizational Behaviour, 31,519542. DOI: $10.1002 /$ job.630

[51] Kairu, P. (2015, August 7). Company offers breastfeeding moms new perk. It is high time employers offered some form of support to breastfeeding mothers in the workplace. Daily Nation, Employment, p.4

[52] Kalish, B. (2014). New Wellness programs focus on finances, not just fitness. Strategy Session, 8-9. Retrieved fromhttps://vpn.uonbi.ac.ke/proxy/http/web.a.ebscohost.com/ehost /pdfviewer/pdfviewer?vid=11\&sid=e0c44563-99df-4d71-b155$06 \mathrm{c} 7 \mathrm{~d} 2 \mathrm{cc} 06 \mathrm{a} 1 \% 40$ sessionmgr4005\&hid $=4107$ on 25.2 .16

[53] Kalleburg, R. (2005). Guidelines for Research Ethics in the Social Sciences, Law And

[54] The Humanities. National Committees for Research Ethics in Norway, 6-44. Retrieved from https://graduateschool.nd.edu/assets/21765/guidelinesresearchethic sinthesocialscienceslawhumanities.pdf on 24.11 .15

[55] Kallinowsky, E., \&Simiyu, M. (2011). Mainstreaming Comprehensive Employee Wellbeing Programmes. Health Kenya, 1-2. Retrieved from http://www.giz.de/fachexpertise/downloads/giz2011-en-kenyapsb-employee-wellbeing.pdf on 20.8 .15 
[56] Keay, E., Macdonald, S., Durand, P., Csiernik, R., \&Wild, T. (2010). Reasons for Adopting and Not Adopting: Employee Assistance and Drug Testing Programs in Canada. Journal of Workplace Behavioural Health, 25(1), 65-71. DOI: $10.1080 / 15555240903358702$

[57] Kocakulah, M. \&Powers, J. (2015). Saving Money through Wellness Programs. Strategic Finance, 23-33. Retrieved from http://web.b.ebscohost.com/ehost/pdfviewer/pdfviewer?vid=3\&sid $=$ f0090c22-9c94-46ef-af05-

8d0b78ac46bd\%40sessionmgr111\&hid=118 on 25.1 .16

[58] Lejeune, T. (2013). Cost savings attributed to self-funding; wellness. Health Care, 18-19. Retrieved from https://vpn.uonbi.ac.ke/proxy/http/web.a.ebscohost.com/ehost/pdf viewer/pdfviewer?vid=6\&sid=e0c44563-99df-4d71-b15506c7d2cc06a1\%40sessionmgr4005\&hid=4107on 25.2.16

[59] Ligami, C. (2012, May 28th- June 3rd). More men dying from Lifestyle Diseases. East African, Science, p.31.Retrieved from http://www.internewskenya.org/summaries/internews4fc4a5eff405 e.pdf on 20.8.15

[60] Lovewell, D. (2009). Ease the Pressure. Healthcare, 31-32. Retrieved

from https://vpn.uonbi.ac.ke/proxy/http/web.b.ebscohost.com/ehost/pdf viewer/pdfviewer?vid=33\&sid=22fe7785-04b8-44c1-908058879053ad69\%40sessionmgr113\&hid $=118$ on 17.10 .15

[61] Lunenburg, F. (2011).Goal-setting Theory of Motivation. International Journal of Management, Business and Administration, 15(1), 1-6. Retrieved from http://www.nationalforum.com/Electronic\%20Journal\%20Volume s/Lunenburg,\%20Fred\%20C.\%20Goal-

Setting\%20Theoryof\%20Motivation\%20IJMBA\%20V15\%20N1 \%202011.pdf on 15.6.15

[62] Lutalo, M. (2007). The Wellness Program of Serena Hotels, Kenya - A Case Study.HIV/AIDS - Getting Results, 1-10. Retrieved from http://gametlibrary.worldbank.org/FILES/1145_Getting\%20results \%20-\%20Kenya\%20Serena\%20hotel.pdf on 25.5 .15

[63] Makumi, D. (2015, November 2). Fighting Cancer. Eating Your Way to Disease and Early Grave. Daily Nation, Opinion, p.13

[64] Managed Care Outlook. (2014). Employers across the Globe Increasingly

[65] See the Value of Wellness Programs, Step up Efforts and Investments. The Insider's Business Briefing on Managed Health Care, 27 (18), 3-7. Retrieved from http://web.b.ebscohost.com/ehost/pdfviewer/pdfviewer?vid=17\&si $\mathrm{d}=\mathrm{f} 0090 \mathrm{c} 22-9 \mathrm{c} 94-46 \mathrm{ef}-\mathrm{af} 05-$ 8d0b78ac46bd\%40sessionmgr111\&hid=118 on 25.1 .16

[66] Mattke, S., Liu, H., Caloyeras, J., Huang, C., Van Busum, K., Khodyakov, D., \&Shier, V. (2013). Workplace Wellness Programs Study. Retrieved from http://www.rand.org/content/dam/rand/pubs/research_reports/RR2 00/RR254/RAND_RR254.sum.pdf on 10.8.15

[67] Mattke, S., Schnyer, C., \&Busum, K. (2012). A Review of the U.S. Workplace Wellness Market. Occasional Paper, 1-48. Retrieved from http://www.dol.gov/ebsa/pdf/workplacewellnessmarketreview201 2.pdf on 10.8 .15

[68] Matunda, C., Miruka, C., \&Moenga, E. (2014).The Impact of Lifestyle Changes on the Prevalence of Cancer in Kenya. Scholars Journal of Applied Medical Sciences (SJAMS), 2(6D), 3064-3070. Retrieved from http://saspublisher.com/wpcontent/uploads/2014/11/SJAMS-26D3064-3070.pdf on 20.8.15

[69] Metropolitan Life Insurance Company. (2013). The MetLife Study of Global Health \&Wellness: A Look at How Multinational Companies are Responding to the Need for a Healthier Workforce. Retrieved

from https://www.metlife.com/assets/institutional/products/benefitsproducts/MetLifeGlobalHealthWellness exp0116.pdf on 10.8.15

[70] Migliaccio, S. (2007). Is Participation in Your Wellness Programs Under the Weather? Incentives and Integration May Be the Cure! Focus On Employee Health Insurance, 14-16. Retrieved from https://vpn.uonbi.ac.ke/proxy/http/web.a.ebscohost.com/ehost/pdf viewer/pdfviewer?vid=33\&sid=e0c44563-99df-4d71-b155$06 \mathrm{c} 7 \mathrm{~d} 2 \mathrm{cc} 06 \mathrm{a} 1 \% 40$ sessionmgr4005\&hid $=4107$ on 25.2 .16

[71] Miguel St. Aubyn., Pina, A., Garcia, F., \& Pais, J. (2009). European Economy: Study on the efficiency and effectiveness of public spending on tertiary education. Economic Papers 390, 1146. DOI: $10.2765 / 30348$

[72] Muda, I., Rafiki, A., Harahap, M. (2014). Factors Influencing Employees' Performance: A Study on the Islamic Banks in Indonesia. International Journal of Business and Social Science, 5(2), 73-80. Retrieved from http://ijbssnet.com/journals/Vol 5 No_2 February 2014/9.pdf on 15.5 .16

[73] Munyi, J. (2012). Kenya Airways Employee Wellness Program. Kenya Airways the Pride of Africa, 1-25. Retrieved from http://www.peopleinaid.org/pool/files/hhr/Nairobi\%202012/Kenya \%20Airways\%20Reflections\%20on\%20Health,\%20Safety\%20an d\%20Wellbeing.pdf on 22.8.15

[74] Muraya, W. (2016, January 23). That's a pot of danger, medics warn on belly fat. The Standard, Health watch, p. 8

[75] National Business Group on Health. (2008). An Employer's Guide to Employee Assistance Programs.Recommendations for Strategically Defining, Integrating, and Measuring Employee Assistance Programs, 1-40. Retrieved from https://www.easna.org/documents/PS2-

NBGRecommendationsforDefiningandMeasuringEAPs.pdf on 25.9 .15

[76] National Institute for Healthcare Management. (2011). Building a Stronger Evidence Base for Employee Wellness Programs. Meeting Brief. Retrieved from http://www.nihcm.org/pdf/Wellness\%20FINAL\%20electonic\%20 version.pdf on 23.8.15

[77] National Park Service Employee Wellness Program Guide. (2014). How to start an Employee Wellness Program. Employee Wellness Program Guide. Retrieved from http://eppley.org/wpcontent/uploads/2014/11/NPS_WellnessGuide.pdf on 21.10.15

[78] Ngeno, W. \&Muathe, S. (2014). Critical Review of Literature on Employee Wellness Programs in Kenya. International Journal of Research in Social Sciences, 4(8), 32-41.Retrieved from http://www.ku.ac.ke/schools/business/images/stories/research/lit_r eview_on_emp_wellness.pdf on 28.8.15.

[79] Otto, N. (2015).Connecting the Wellness Dots. Employee Benefit News, 28-29. Retrieved from https://vpn.uonbi.ac.ke/proxy/http/web.b.ebscohost.com/ehost/pdf viewer/pdfviewer?vid=55\&sid=7d9dc763-ab82-4271-993ce8daa4373873\%40sessionmgr102\&hid $=102$ on 30.1 .16

[80] Oyewo, A., \&Akanbi, T. (2012). Marital Stress Spill over as a Predictor of Job Performance among Married Civil Servants in Oyo State, Nigeria. European Journal of Humanities and Social Sciences, 14(1), 696-709. Retrieved from http://www.journalsbank.com/ejhss_14_4.pdf on 3.10.15

[81] Ozguner, Z., \&Ozguner, M. (2014). A Managerial Point of View on the Relationship between Maslow's Hierarchy of Needs and Herzberg's Dual Factor Theory. International Journal of Business and Social Science, 5(7), 207-215. Retrieved from http://ijbssnet.com/journals/Vol_5_No_7_June_2014/26.pdf on 24.8 .15

[82] Paterson, J. (2013). Employers must promote better staff healthcare. Business Source Premier, 1. Retrieved from https://vpn.uonbi.ac.ke/proxy/http/web.b.ebscohost.com/ehost/deta il/detail?vid=23\&sid=22fe7785-04b8-44c1-908058879053ad69\%40sessionmgr113\&hid=118\&bdata=JnNpdGU9Z Whvc3QtbGl2ZQ\%3d\%3d\#AN=92639843\&db=buh on 17.10 .15

[83] Patton, C. (2015). 5 Employee Benefits to Add To the Mix. Campus Finance, 57-59. Retrieved from https://vpn.uonbi.ac.ke/proxy/http/web.a.ebscohost.com/ehost/pdf viewer/pdfviewer?vid=5\&sid=e0c44563-99df-4d71-b155$06 \mathrm{c} 7 \mathrm{~d} 2 \mathrm{cc} 06 \mathrm{a} 1 \% 40$ sessionmgr4005\&hid $=4107$ on 25.2 .16

[84] Perkins, Ann. (2009). Medical costs. Reducing Stress, 12. Retrieved from https://vpn.uonbi.ac.ke/proxy/http/web.b.ebscohost.com/ehost/pdf 
viewer/pdfviewer?vid=30\&sid=22fe $7785-04 \mathrm{~b} 8-44 \mathrm{c} 1-9080$ 58879053ad69\%40sessionmgr113\&hid $=118$ on 17.10 .15

[85] Pidd\&Roche. (2013). Workplace alcohol and other drug programs: What is good practice? Policy Talk. Retrieved from http://www.adf.org.au/policy-talk-workplace-alcohol-and-otherdrug-programs-july-2013 on 15.10 .15

[86] Prudential Group Insurance. (2012). Study links well-being; job performance, Productivity, 1. Retrieved from https://vpn.uonbi.ac.ke/proxy/http/web.b.ebscohost.com/ehost/pdf viewer/pdfviewer?vid=35\&sid=22fe 7785-04b8-44c1-908058879053ad69\%40sessionmgr113\&hid=118 on 17.10 .15

[87] Robertson, H. (2008). Definitions: Employee, Volunteer, Intern, or Independent Contractor in context of Employment vs. Unauthorized Employment. Retrieved from http://international.cua.edu/res/docs/immigrationbasics/employeevs-volunteer.pdf on 22.3.16

[88] Rogers Publishing Limited. (2013). Workplace benefits deliver healthy results. Business Source Premier, 32(6). Retrieved from https://vpn.uonbi.ac.ke/proxy/http/web.b.ebscohost.com/ehost/deta il/detail?vid=3\&sid=22fe 7785-04b8-44c1-908058879053ad69\%40sessionmgr113\&hid=118\&bdata=JnNpdGU9Z Whvc3QtbGl2ZQ\%3d\%3d\#AN=92638787\&db=buh on 17.10 .15

[89] Rombel, A. (2007). Wellness programs play bigger role in benefit plans. Special Report: Employee Benefits\&HR, XXI (46), 17-19. Retrieved from https://vpn.uonbi.ac.ke/proxy/http/web.b.ebscohost.com/ehost/pdf viewer/pdfviewer?vid=49\&sid=7d9dc763-ab82-4271-993ce8daa4373873\%40sessionmgr102\&hid $=102$ on 30.1 .16

[90] Rono, W. (2011). Factors that influence adoption of Employee Wellness Programs at the Standard Group Limited, 1-51. Retrieved from http://erepository.uonbi.ac.ke/bitstream/handle/11295/13459/Facto rs\%20that\%20influence\%20adoption\%20of\%20employee\%20wel lness \%20programs\%20at\%20the\%20standard\%20group\%20limite d.pdf? sequence $=3$ on 20.8 .15

[91] Schoenman, J. (2011). Building a Stronger Evidence Base for Employee Wellness Programes. NIHCM Foundation. Retrieved from

http://www.nihcm.org/pdf/Wellness\%20FINAL\%20electonic\%20 version.pdf on 23.8 .15

[92] Seligman, M. (2005). The Corporate Chill Pill. Executive Health, 64-66. Retrieved from https://vpn.uonbi.ac.ke/proxy/http/web.b.ebscohost.com/ehost/pdf viewer/pdfviewer?vid=31\&sid=22fe 7785-04b8-44c1-908058879053ad69\%40sessionmgr113\&hid $=118$ on 17.10 .15

[93] Serem, S. (2015). Public Sector Remuneration and Benefits Policy. Republic Of Kenya, 1-25. Retrieved from http://www.src.go.ke/pdfdocuments/PUBLIC\%20SECTOR\%20R EMUNERATION\%20BENEFITS\%20POLICY\%20Final\%20draft.pdf on 5.2.16

[94] Shelby, L. (2015). Employers tackle increasing cost of health care. Business Insurance, 49(24), 1-3. Retrieved from https://vpn.uonbi.ac.ke/proxy/http/web.a.ebscohost.com/ehost/deta il/detail?vid=44\&sid=e0c44563-99df-4d71-b155$06 \mathrm{c} 7 \mathrm{~d} 2 \mathrm{cc} 06 \mathrm{a} 1 \% 40$ sessionmgr4005\&hid=4107\&bdata $=$ JnNpdGU9 ZWhvc3QtbGl2ZQ\%3d\%3d\#AN=111245464\&db=f5h on 25.2.16

[95] Spicer, A. (2015). Defend Your Research Corporate Wellness Programs Make Us Unwell, Harvard Business Review, 28-29. Retrieved

from http://web.b.ebscohost.com/ehost/pdfviewer/pdfviewer?vid=15\&si $\mathrm{d}=\mathrm{f} 0090 \mathrm{c} 22-9 \mathrm{c} 94-46 \mathrm{ef}-\mathrm{af05}-$ 8d0b78ac46bd\%40sessionmgr111\&hid $=118$ on 25.1 .16

[96] Stonehouse, A. (2014). A Challenging Path to Wellness Employee Benefit News, 19-20. Retrieved from https://vpn.uonbi.ac.ke/proxy/http/web.a.ebscohost.com/ehost/pdf viewer/pdfviewer?vid=7\&sid=e0c44563-99df-4d71-b155$06 \mathrm{c} 7 \mathrm{~d} 2 \mathrm{cc} 06 \mathrm{a} 1 \% 40$ sessionmor4005\&hid $=4107$ on 25.2 .16

[97] Tech Target. (2007-2015). employee assistance program (EAP) definition. Retrieved from http://searchcio.techtarget.com/definition/employee-assistanceprogram on 8.9.15

[98] The California Wellness Foundation. (2015). Public Health \&Philantropy Lexicon. The California Wellness Foundation promoting equity, advocacy and access. Retrieved from http://www.calwellness.org/resources/lexicon_efgh.php\#h on 6.9.15

[99] The Institute for Health and Productivity Studies. (2016). Physical Activity in the Workplace. A Guide for Employers, 1-10. Retrieved from http://whrn2-chaicore.vipapps.unc.edu/wpcontent/uploads/2016/05/CDC-WHRN-PhysicalActivity_Employer-Guide-FINAL.pdf on 25.10.16

[100] Tongoi, C. (2013). Employee health and wellness survey. A mixed method study on the health knowledge, attitude, perception and behaviour of Contracted employees in Kenya. Hamburg University of Applied Sciences, 1-115. Retrieved from http://edoc.sub.uni-

hamburg.de/haw/volltexte/2014/2555/pdf/MACharity

MugureTongoi.pdf on 25.8.15

[101] Tuwai, B., Kamau, C., \&Kuria, S. (2015). Effect of Corporate Wellbeing Practices on Employees' Performance among Commercial Banks in Kenya. International Journal of Scientific and Research Publications, 5, 1-16. Retrieved from http://www.ijsrp.org/research-paper-0515/ijsrp-p4124.pdf on 27.8 .15

[102] Ueda, Y., \& Yoko Ohzono (2013). Differences in Work Values by Gender, Marital Status, and Generation: An Analysis of Data Collected from "Working Persons Survey, 2010". International Journal of Human Resource Studies, 3(2), 28.41. DOI: 10.5296/ijhrs.v3i2.3131

[103] Valet, V. (2015). More Than Two-Thirds Of U.S. Employers Currently Offer Wellness Programs, Study Says. Business Source Premier, 1-2. Retrieved from https://vpn.uonbi.ac.ke/proxy/http/web.a.ebscohost.com/ehost/deta il/detail?vid=4\&sid=e0c44563-99df-4d71-b155$06 \mathrm{c} 7 \mathrm{~d} 2 \mathrm{cc} 06 \mathrm{a} 1 \% 40$ sessionmgr4005\&hid $=4107 \&$ bdata $=\mathrm{JnNpdGU9}$ ZWhvc3QtbGl2ZQ\%3d\%3d\#AN=108266885\&db=buh on 25.2.16

[104] Vernon, C. (2010).Corporate Wellness programs benefit workers while saving companies money. The Enterprise, Health Matters, p.10. Retrieved from https://vpn.uonbi.ac.ke/proxy/http/web.b.ebscohost.com/ehost/pdf viewer/pdfviewer?vid=22\&sid=ae75ff95-8021-4775-8c01-

10decaffb06b\%40sessionmgr115\&hid=124 on 21.2.16

[105] Vogel, C. (2015). What's working: Tracking Wellness Data. Benefits Magazine, 52(5), 11-13. Retrieved from https://vpn.uonbi.ac.ke/proxy/http/web.b.ebscohost.com/ehost/pdf viewer/pdfviewer?vid=17\&sid=ae75ff95-8021-4775-8c0110decaffb06b\%40sessionmgr115\&hid=124 on 20.2.16

[106] Willingham, J. (2008). Managing Presenteeism and Disability to Improve Productivity: Benefits Compensation Digest, 45(12), 1114. Retrieved from http://www.ifebp.org/inforequest/0155525.pdf on 10.12 .15

[107] World Health Statistics Report. (2010). Global status report on noncommunicable diseases 2010. Retrieved from http://www.who.int/nmh/publications/ncd_report_full_en.pdf on 7.2 .16

[108] Yusoff, R., Ali, A\&Khan, A. (2014).Assessing Reliability and Validity of Job Performance Scale among University Teachers. Journal of Basic and Applied Scientific Research, 4(1)35-41. Retrieved from http://www.textroad.com/pdf/JBASR/J.\%20Basic.\%20Appl.\%20S ci.\%20Res., \%204\%281\%2935-41,\%202014.pdf on 18.3.16 